\title{
Tekstteori: Tekstteorien og den problematiske grænseflade mellem sprog og handling
}

\author{
Peter Harder \\ Denne artikel er et diskussionsindlæg der forsøger at perspektivere \\ forrige nummers artikler i forhold til den fælles problemstilling. \\ Det overordnede perspektiv der er valgt, er tekstbeskrivelsen som \\ et mødested for fundamentalt forskellige teoretiske indfaldsvinkler, \\ især den sproglige systembeskrivelse og den pragmatiske hand- \\ lingsbeskrivelse. Der er lagt særlig vægt på vanskelighederne med \\ at skille dem tilstrækkelig klart fra hinanden, hvilket er nødvendigt \\ for at kunne vise hvad de hver især kan bidrage med. På basis heraf \\ diskuteres de enkelte bidrag og deres forskellige pointer i forhold til \\ problematikken.
}

Temanummeret om tekster anskuet i sproghandlingsteoretisk perspektiv leverer en velkommen opsamling på en vigtig diskussion.

I 1970'erne vendte lingvistikken tilbage til teksten - det filologiske kerneområde som sprogvidenskaben var brudt ud af med strukturalismen - med erobrerglimt i øjet. Det betød at tekster blev nylanceret som genstand for sprogvidenskabelig interesse, og der blev fremsat en række programmatiske beskrivelser og iværksat forskning på basis af dem, hvilket betød at der i en periode var en art samlet bevidsthed om den udfordring tekstbeskrivelsen stillede lingvistikken over for. Denne bevidsthed er i nogen grad diffunderet bort igen siden dengang, trods bestræbelser på at fastholde problematikken (ikke mindst af bidragyderne til dette nummer, jf. Togeby 1993; Borchmann 2005).

Denne udvikling er i en vis forstand uundgåelig, fordi tekster ikke udgør et stramt struktureret og meget specifikt beskrivelsesdomæne - et gennemgående motiv i nummeret. Tekster hænger sammen med resten af verden i så mange forskellige punkter (jf. Jan Svensson's bidrag om 'teksten som hydra'), at beskrivelsen af dem nødvendigvis må trække 


\section{Tekstteori}

i vidt forskellige retninger. Det store brag i tekstbeskrivelsen og den fremadskridende udvidelse af universet hverken kan eller skal bremses. Det betyder på den anden side at der er et stort behov for med mellemrum at danne sig overblik over forholdet mellem mangfoldigheden og det generelle.

Et centralt bidrag til overblikket leveres i Simon Borchmanns indledning, som gør grundigt op med en af de vigtigste kilder til forvirring omkring tekster som beskrivelsesgenstand, nemlig sprogsystemets status som bagmand for tekstvidenskaben. Tre væsentlige tråde i denne kritiske fremstilling er implikationerne af grammatikalitetstestens udvidelse til tekstteorien ('er følgende sætningssekvens en mulig tekst?'), kohæsionsbegrebet som kriterium for om noget kan være en tekst, og det logiske udsagns udvidelse til at være basis for tekstuelle makrostrukturer. Alle tre er centrale fejlkilder, som bliver nøje analyseret.

Det sidste er teoretisk forskelligt fra de to første, fordi logikkens udsagnsbegreb ikke er sprogsystematisk funderet i klassisk forstand sandhedsværdier er ikke indbygget i 'langue' - men det repræsenterer en analog fejlkilde, som i 70-erne var let at identificere med sprogsystemet, dengang den sprogstrukturelle formaliseringstradition blev invaderet af den logiske formaliseringstradition med Montague som spydspids, og det $\mathrm{i}$ en lang periode var svært at se forskel mellem de to traditioners implikationer.

Forståelsen af hvorfor en handlingsbetragtning er grundlæggende nødvendig for at forstå de sammenhængsrelationer som teoretikerne med rette peger på, er den anden side af den diskussion, der retter sig imod den sprogsystematiske indfaldsvinkels mangler. Borchmann viser her hvorfor sproghandlingsteorien i dens klassiske filosofiske udformning, der tager en (især sætningsformet) ytring ad gangen, kræver udvidelser for at kunne blive grundlag for en tekstteori; men i stedet for at opnormere dette til at være en uoverskuelig kløft, påviser han pragmatisk hvilke forbindelseslinjer der skal etableres (til genreteori, kognitionspsykologi m.v.). Afslutningsvis definerer han hovedspørgsmålet for temanummeret: hvis man anlægger den grundlæggende handlingsoptik, hvilke konsekvenser har det så for teksten som handlingsmæssig kompleks beskrivelsesgenstand, hvor handlingsbegreberne kan anlægges på alle niveauer fra den enkelte sætning til teksten under ét? 


\section{Peter Harder}

Jan Svenssons pointering af tekstens hydra-egenskaber fører ham til en overordnet tredeling mellem sætningsgrammatik, tekstteori og handlingsteori. Med udgangspunkt i denne tredeling kan man opfange nogle generelle typer af forskelle og ligheder. Opdeling i konstituenter kan gennemføres for sætninger, tekster og komplekse handlinger (såsom rejseplanlægning!) - men det er ikke de samme slags konstituenter på de tre niveauer, selvom de kan ligne mere eller mindre; såvel sætninger som tekster og handlinger har succeskriterier, men heller ikke de er af samme karakter: Grammatikalitet, kohærens og 'vellykkethed' kan ikke slås sammen til én ting, osv.

Generalisationer på tekstniveau vanskeliggøres af hydraproblemet - medmindre man vælger tekster 'strategisk' ved på forhånd at skæve til generaliseringsmulighederne (forretningsbreve osv.). Som illustration af den utæmmelige kompleksitet ved dette genstandsområde gør han det interessante at han gennemgår en tekst der er valgt netop fordi den ikke lader sig indfange i klare præ-eksisterende strukturer, og som derfor på umiddelbart slående vis instantierer kreativitet snarere end præ-eksisterende regelmæssighed. Det drejer sig om en beretning om Gunnar Sträng, indlejret i en beskrivelse af Lars Lindblad, indlejret i en bog om Absolut Vodkas sejrsmarch i USA. Eksemplet er en helt vidunderlig biografisk beskrivelse af Gunnar Sträng, der er koblet til temaet via hvad den siger om Lindblad; og Svensson giver en plausibel men indrømmet personlig-interpretativ beskrivelse af hvad der er at sige om denne tekst med henvisning til alle relevante udgangspunkter. Pointen om at tekster bevæger sig igennem et mulighedsrum der ikke er forstruktureret på anden måde end ved forfatterens strategiske valg, illustreres på smukkeste vis.

Ikke desto mindre er der selv i denne tekst et lille nedslag af afklaringsproblemerne $\mathrm{i}$ forhold til systemlingvistikken. Tredelingen $\mathrm{i}$ sætningslingvistik, tekstteori og handlingsteori betragtes i slutningen som perspektiver man kan anlægge på beskrivelsen, og sættes som sådanne $\mathrm{i}$ forhold til sondringen mellem sprogsystem og sprogbrug. Svensson placerer dem på basis heraf på en måde der er intuitivt bestikkende, men alligevel reproducerer det basale problem som beskrevet af Borchmann: sætningsgrammatikken er næsten helt på systemsiden, teksten er i noget mindre grad system, og sproghandlingsteorien er næsten helt på sprogbrugssiden.

Men hvis man tror på at der er et systemniveau (hvad jeg selv mener er nødvendigt - ellers behøvede man ikke at lære sprog, kun konkrete ytringer), må man fastholde at de sider af sætningsgrammatikken som 
er sværere at sætte på klare formler, også er en del af systemet, ikke af sprogbrugen. Systemet kan være mere eller mindre systematisk, så at sige - det er stadig noget andet end sprogbrug. Sætninger kan naturligvis forekomme som en del af sprogbrugen, men sætningsgrammatikken kan ikke: den må som sådan være et system-fænomen (og altså ikke 'hovedsagelig' et systemfænomen). Og hvis vi antager at Svensson i virkeligheden ikke mente sætningsgrammatikken, men beskrivelsen af sætninger (som grammatikken så kunne klare en større del af end den kan af hele tekster), kan det ikke legitimere hans formulering - for sætninger i brug er et særtilfælde af tekster (meget korte tekster) - jf. Oscar Wilde's sidste ord 'Jeg dør over evne!'.

Tilsvarende er tanken om at sproghandlingsteorien kan have en lillefinger af systemtanken i sig, intuitivt plausibel, hvis man antager at der er en lille del af systemet der har en illokutiv snært (måske kan sondringen mellem sætningstyperne være det der ligger bag?). Men det er principielt heller ikke muligt: en ytrings identitet som handling er restløst et brugsfænomen. Selvfølgelig trækker sproghandlinger på sprogsystemet, lige som tekster gør - men det betyder ikke at de sproglige egenskaber er afgørende for handlingsidentiteten.

Det Svensson med rette peger på, er altså principielt noget andet: det drejer sig om en heuristisk skala for hvor langt man kan komme med sproglig viden i de tre domæner: længst i sætningsbeskrivelsen, knap så langt i tekstbeskrivelsen, og ikke ret langt i handlingsbeskrivelsen. Man kunne så vælge at sige: Det er tydeligvis det han mener - hvorfor så holde fast i den pernittengrynede principdiskussion? Fordi det, som Borchmann påpeger, er vigtigt at få forvirringen om sprogsystemets status helt udryddet. At forvirringen faktisk er til stede i Svenssons artikel, kan man se af det illustrative diagram der bringes mod slutningen: i den mest 'systemnære' cirkel står der rent ud 'system' - men denne cirkel er anbragt sådan at en lille del hører hjemme på 'brugs-halvdelen' af boksen. Det turde heroverfor være indlysende at systemets rette plads må være éntydigt på system-siden - ikke 95\%, men 100\%. Det er sikkert en trykfejl - der skulle have stået 'sætningsgrammatik' i stedet for 'system' i den første cirkel - men det er ikke tilfældigt at denne trykfejl kan opstå.

Ole Togeby fokuserer på det centrale spørgsmål om forholdet mellem den samlede teksthandling og de enkelte sproghandlinger den er opbygget af. Enkelthandlingerne analyseres på basis af det klassiske begreb om en propositionel kerne og en illokutionær værdi opdelt i de tre grundtyper med hver sin habermasianske norm tilknyttet: 
konstativer (bundet til en norm om sandhed), ekspressiver (med norm om ærlighed) og regulativer (med norm om retmæssighed). Den samlede teksthandling beror i Togebys analyse på konneksionerne; der er her et bottom-up-element der knytter tekstteorien tættere til det underliggende niveau end Svenssons betragtning. Der er den vigtige pointe i denne anskuelsesmåde at teksten er noget overlejret i forhold til enkeltdelene: de basale sætningers bidrag tilføres en ny, tekstlig dimension ved at blive sat sammen og forbundet på en meningsberigende måde. Denne operation ses også som noget der (i vidt omfang, men ikke nødvendigvis i alle tilfælde) nedgraderer enkeltsætningernes handlingsværdi: de griber ikke alle direkte ind i den situation teksten taler ind i, nogle sætninger har nødvendigvis en opgave i forhold til andre sætninger i teksten.

Det betyder at der er et dobbelt svar på spørgsmålet, analogt med tankegangen i den hermeneutiske cirkel: på den ene side dannes der en samlet teksthandling ud fra enkelthandlingerne, på den anden side undertvinges den enkelte handlings betydningspotentiale i kraft af kravet om at det skal underordnes den samlede teksthandling. Bottomup-niveauet, med fokus på hvilke komplicerede strukturer man kan bygge af dem, er dog nok det der kommer stærkest til udtryk i teksten: fremstillingen knytter an til Blixen-analysen (jf. Sørensen og Togeby 2001), og giver et par udsøgte eksempler på ciselerede tekstpagoder a la Mandelbrot og russiske babusjka-dukker.

Igen vil jeg imidlertid give et eksempel på at forholdet mellem handling og sproglig betydning stadig trænger til fuld afklaring. Som nævnt antages enkelthandlingen at være opbygget som hos Searle med en proposition der tilknyttes en handlingsværdi, en illokution. Dette udgør startpunktet for artiklen, hvor eksemplet er ytringen 'Tusind tak'. Searles analyse (som citeres) er at det propositionelle indhold er den handling der takkes for - men Togeby påpeger med rette at denne handling er forudsat og ikke fokuseret indhold i taksigelsen. Det fokuserede, og dermed sagforholdet i ytringen, er "As reaktion på Ms forudgående handling". Men det skaber et nyt problem. Det betegner nemlig ikke det indhold der tilskrives en handlingsværdi, som 'jeg kommer' kan tilskrives den illokutionære værdi 'løfte' i ytringen 'jeg lover dig at jeg kommer'. I stedet betegner det selve sproghandlingen som helhed - det er en performativ formel. Det gælder med andre ord indholdet på det illokutionære niveau: 'As reaktion på Ms forudgående handling' er at takke ham. Et analogt tilfælde er 'Jeg undskylder', hvor det sproglige indhold også betegner selve handlingen, og ikke angiver et sagforhold der skal tilskrives en handlingsværdi. 


\section{Tekstteori}

Handlinger kan derfor ikke generelt opdeles i to dele, hvoraf den ene er det propositionelle indhold og den anden er den illokutionære kraft det udsagte indhold har. Inddelingen må gå på en anden led, hvis den skal opretholdes: mellem det sproglige niveau for den indkodede betydning (hvor 'jeg takker dig' udgør en proposition, ganske som 'Jensen takkede ham'), og det handlingsmæssige niveau for den illokutionære værdi (hvor 'jeg takker dig' er en tak, mens 'Jensen takkede ham' er et konstativ). Selvom problemet er et andet end hos Svensson, er der den principielle lighed, at grænsefladerne mellem sprog og tekst stadig ikke er fuldt afklaret.

Lita Lundquists artikel handler ikke om tekster, men om sproghandlinger, nærmere bestemt om humoristiske talehandlinger i dansk og fransk. Emnet er den form for hybride handlinger der ikke skal tages bogstaveligt, men alligevel tæller som sproghandlinger, bare 'bone-fide-cum-humor' snarere end bogstaveligt forståede. Der er den sammenhæng med teksttemaet, at argumentationen viser hvordan den vellykkede tilskrivning af handlingsværdi kan slå fejl i en tværkulturel sammenhæng af grunde der både har med sprogsystemet at gøre og med makro-kulturen på nationalt niveau - altså helt nedefra og helt oppefra på samme tid. Den danske kodningsstrategi rummer elementer der fokuserer på modtagerens fortolkning (den modtagerorienterede supertype ifølge Durst-Andersen 2011), som ikke spiller samme rolle i fransk - og samtidig er der kommunikative praksisser i Frankrig der hænger sammen med den franske hierarkiske tradition fra Solkongens tid, der står i kontrast til den flade struktur i dansk social forståelse. Ytringer der tematiserer modtagerens position i helheden er ofte ikke morsomme fra begge perspektiver samtidig!

Kjell Lars Berge tager mange af de tidligere berørte grundtemaer op om enkeltdelene og den samlede sproghandling, om nødvendigheden af at have en sagforholds- og en ytringsdimension, og om paralleller mellem de forskellige analyseniveauer. Ud fra det tema jeg har anslået, om at søge efter de fortsat problematiske grænseflader mellem de forskellige perspektiver, er der særlig et punkt der kalder på nærmere granskning. Det drejer sig igen om forholdet mellem det sproglige og det handlingsmæssige aspekt.

I analysen af et teksteksempel hedder det (på basis af en velbegrundet antagelse om at teksten følger sprognormerne) om inddelingen i enkeltdele at "vi kan dele...op i ytringer som oppfyller kravene til setninger, at de har subjekt og finit verbal". Her glider

fremstillingen uden overgang fra en opdeling $\mathrm{i}$ ytringer til en opdeling $\mathrm{i}$ 
sætninger, uden at man overvejer om kriterierne for at inddele i ytringer nødvendigvis fører til en opdeling i sætninger. Problemet aktualiseres derved at tekstuddraget rummer den komplekse sætning Begrepene, slik jeg vil bruke dem, opererer innen to forskjellige sfoerer av et hele, som analyseres i to ytringer (p. 96):

7. Begrepene (...) opererer innen to forskjellige sfærer av et hele 8. Slik jeg vil bruke dem

Denne antagelse støttes med henvisning til Hallidays begreb om kongruens mellem et indholdsplan bestående af propositioner og handlinger på den ene side og et udtryksplan bestående af skriftsproget på den anden, således at hver ytring kan forstås som en finit sætning.

Der er to problemer, et konkret og et principielt: det konkrete er at man normalt ikke ville opfatte en ledsætning som slik jeg vil bruke dem som en ytring. Det principielle problem er spørgsmålet om kriterierne - der ikke ekspliciteres - for denne beskrivelse, men hvor Halliday i stedet inddrages som garant. Jeg har tidligere redegjort for mine betænkeligheder ved systemisk-funktionel lingvistiks beskrivelsespraksis (jf. Harder 2005:26-35), herunder spørgsmålet om kongruens mellem indhold og udtryk, når der ikke er klare kriterier for hvad der antages at være indholdsstrukturen. Pointen i denne sammenhæng er at en uproblematiseret antagelse om kongruens i hvert fald ikke sikrer klarhed om eventuelle problemer i grænsefladen mellem sproglige og handlingsmæssige strukturer.

Den sidste artikel er klart uden for temaet og handler om sprognormer i relation til sociolingvistisk variation, men jeg vil alligevel slutte med kraftigt at anbefale den. Blandt dens fortræffeligheder er at den viser at kønsaspektet er det eneste der varierer i et ellers helt entydigt billede af hvordan konservativ og moderne københavnsk samt lokalfarvet udtale placeres i en masketest i fem forskellige danske byer - samt at den siger så klart som jeg ikke tidligere har set det i sociolingvistisk litteratur, at fordomme er en simpel psykologisk nødvendighed (p. 133)!

\section{Litteratur}

Borchmann, Simon U. (2005) Funktionel tekstteori og fiktivt fortcellende tekster med refleksiv funktion. København: Roskilde Universitetsforlag.

Durst-Andersen, Per (2011) Linguistic Supertypes: A cognitive-semiotic theory of human communication. Berlin: De Gruyter Mouton. 
Harder, Peter (2005) Dansk Funktionel Lingvistik: en introduktion. I Dansk Funktionel Lingvistik - en helhedsforståelse af forholdet mellem sprogstruktur, sprogbrug og kognition. Elisabeth Engberg-Pedersen, Michael Fortescue, Peter Harder, Lars Heltoft, Michael Herslund og Lisbeth Falster Jakobsen. København: Københavns Universitet, Handelshøjskolen i København og Roskilde Universitetscenter.

Sørensen, Ivan Z. og Ole Togeby (2001) Omvejene til Pisa. En fortolkning af Karen Blixen »Vejene omkring Pisa«. København: Gyldendal.

Togeby, Ole (1993) Praxt: Pragmatisk tekstteori. Århus: Aarhus University Press.

Peter Harder

Institut for Engelsk, Germansk og Romansk

Københavns Universitet

harder@hum.ku.dk 